\title{
The Kitchen: An Architectural Mirror of Everyday Life and Societal Development
}

\author{
Claus Bech-Danielsen \\ Danish Building Research Institute, Aalborg University, Denmark
}

\begin{abstract}
This paper is part of a research project that analyses trends in housing architecture over the past 100 years. The research aims toshow how changing norms and new forms of everyday life have altered our views on housing and have led to fundamental changes in housing architecture. In this paper the analysis focuses particularly on the kitchen. A hundred years ago the kitchen of the bourgeoisie and the middleclass was only used by servants and other employees. Accordingly, the design of the kitchen was not a task for architects at all. However, during the 20th century the kitchen became an important architectural focal point. In the early part of the century architects considered it a practical workspaceto beimproved through rational analysis. Later on the kitchen was seen as a space with great social qualities, and the informal character of the kitchen was developed and exported to the rest of the dwelling. Today the kitchen has become the central space in many dwellings, but as the dwelling is increasingly being rendered representative value, modern kitchens are designed with emphasis on their aesthetic appearance. They are "life-style kitchens", which demonstrate the "good taste” of the residents and reflect their personalities.
\end{abstract}

Key words: Kitchen design, housing architecture, cultural trends.

\section{Introduction}

This paper is part of a research project that surveys a series of momentous changes in residential architecture in the last 100 years. This was done by focusing on a number of specific functions of the dwelling, specifically the kitchen. How did the actual work in the kitchen and the view of kitchenwork change throughout the 20th century and how did this affect the spatial organization of the dwelling and the practical design of kitchens?

Primary focus is on developments in Danish housing. However, international developments have also been included, if they have been important for changes in Denmark. This means that the relationship between international developments and Danish developments varies in the description of the various periods. In particular during the period 1920-1930, change was primarily on the international stage rather than in

Corresponding author: Claus Bech-Danielsen, PhD, professor, research field: housing architecture. E-mail: cbd@sbi.dk.
Denmark, but in the post-war period, focus turned to concentrate on developments in the kitchen in Denmark, so this section focuses more on Danish conditions.

The method included literature studies. On the one hand these studies focused on societal and cultural trends (health, hygiene, rationality, food culture, gender, sustainability, consumerism etc.) and on the other hand they focused on housing architecture, changing residential conditions as well as kitchen design. A number of typical house plans of the periods have also been analyzed. These analyses primarily focused on the spatial conditions of kitchens - the size, the location and the design of kitchens. The emergence of conditions typical of each individual period was often discovered through comparison across the different periods.

This paper presents some results of the study. It will be shown how kitchen design and its relation to everyday life in the dwelling has changed over time. With focus on the kitchen, it is shown that housing architecture has undergone drastic changes over the 
last 100 years. Thus it becomes obvious that the concept of "good housing" has constantly been changing. We may imagine that housing today will meet future housing needs, but in the light of the previous changes, we have to recognize, that the future is also likely to bring great changes.

\section{Once Upon A Time - Kitchens 100 Years Ago}

In the early 1900s it was rare to find a woman from the middle class or the bourgeoisie in her kitchen. The American housing researcher Sudjic compares contemporary kitchens with the engine room of a ferry: it was a workspace for the crew and a place where passengers were unwelcome [15]. The kitchen was the domain of the servants, and the role of the housewife in relation to work in the kitchen was that of an employer $[4,15]$. Her only contact with the staff was when the cook or the housekeeper went upstairs to the living rooms in order to discuss the menu for the day.

Thus, at this time having a nice kitchen was not associated with status. Cooking was associated with hard and dirty work: firewood was carried, meals were prepared from scratch, smoke and dust came from the cooking range etc., and the status related to the kitchen was usually based on the number of servants employed [3]. The servants' work in the kitchen was not meant to be seen, heard or smelled in the rest of the dwelling. Neither guests nor masters were supposed to concern themselves with the work in the kitchen, and they met the servants as less as possible.

In contemporary housing the kitchen was therefore located far from the primary spaces of the dwelling. In this context it should be remembered that contemporary housing had a strong representative character. In villas the kitchen was typically located in the basement, next to laundry, coke depot, servants' rooms, etc., and in multi-storey buildings the kitchens were located in the "private section" of the dwelling and always oriented towards the backyard (see Fig. 1). The advantage was that noise, smoke and smell did not spread to the representative part of the house, but at the same time it meant that the kitchen was located far from the dining room. This was inconvenient for the workflow around cooking and serving, but quite logical in a period where the comfort of the gentry took priority over convenient working conditions for the servants.

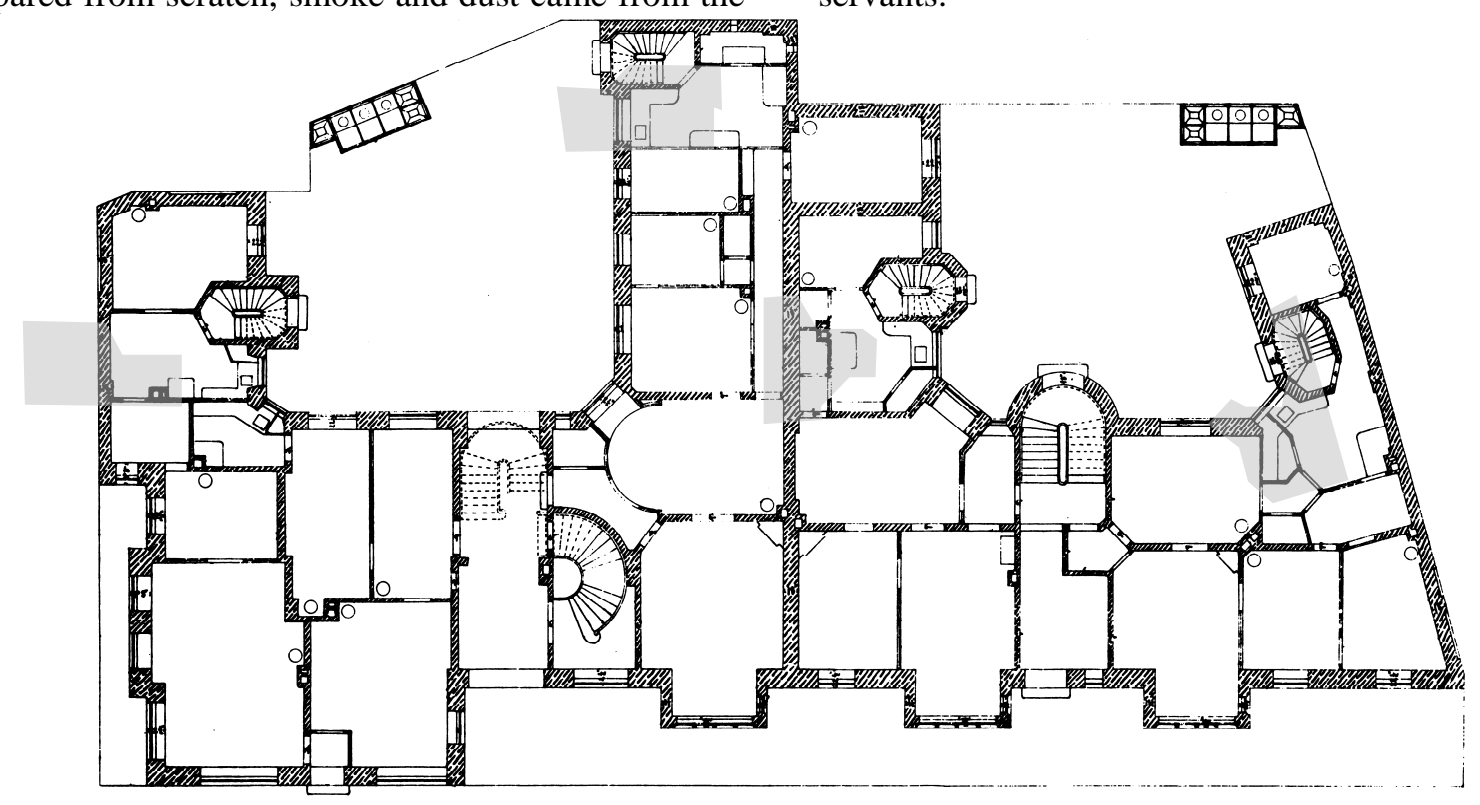

Fig. 1 Danish Housing from 1898: The kitchens are oriented towards the backyard, they have scattered furnishing and no coherent layout. 
There was ample space in the houses of prosperous citizens, and kitchens were also relatively spacious. They served as both work and dining areas for the staff [18], and a table was usually placed in the middle of the kitchen around which employees could eat their meals. A number of rooms were related to the kitchen: a cool pantry for storing food was a necessary part of contemporary kitchens and in the large residences there was even a pantry where the food was arranged before being carried into the dining room.

Since kitchens were spacious, since it was easy to find cheap domestic servants, and since no one was interested in the working conditions of servants, no one focused on the kitchen as an important workplace. Kitchen layout was dictated by other factors [14]. For instance the position of the chimney dictated the position of the stove, and as the chimney was supposed to double as a heat source and exhaust duct for more than one room, the chimney was usually located well inside the house and away from the windows. Of course this made it difficult to ventilate the kitchen for smoke and heat. The sink, on the contrary, hung on the wall facing the backyard, as the wastewater was drained directly into the courtyard (until a sewerage system was implemented).

Usually there were many doorways in a kitchen. One door served as the entrance to the kitchen - typically from a corridor, another door led to a pantry, and often other doors would lead to a storage area and a staircase. The many doorways made it difficult to establish a coherent layout for the kitchen and scattered furnishing was emphasized by the fact that kitchen components were still not arranged to form a cohesive whole in an overall design [14]. The stove was one single element, the kitchen sink hung by itself, and each piece of furniture for storage might be located in different places, and was not designed specifically for the particular space.

\section{Modernism and Kitchen Design in the 1920s and 1930s}

When modernists in the 1920s and 1930s developed modernistic architecture, not only housing for the wealthy was on the agenda. The architects of modernism would develop housing for the general population, and since the general population had no servants, the kitchen became an architectural topic and a significant new venture for architects. Previously architects had dealt with monumental buildings and palaces for the upper class, and as kitchen work had never been a part of their daily lives, kitchen design had never been on the architectural agenda. Thus the task was entirely new.

The architects of modernism were inspired by engineers who developed new types of products: cars, airplanes, bridges, ocean liners, etc. Engineers had their rational way of working and, as they were more familiar with new materials and mechanical production methods, they had taken the lead in designing these new products. Modernists based their design of new homes on similar rational considerations, and in so doing the kitchen was an obvious place to focus. Specific functions were performed in the kitchen, and the kitchen was therefore the perfect place to realize the concept of modernism. It was an ideal place to demonstrate rational methods and functional analysis to streamline the workflow and optimize use of space.

The trend had already been developed for some time. Christine Frederick [5], who was an American co-editor of Ladies Home Journal, made herself the protagonist of the work, and in 1919 she published the book "Household Engineering: Scientific Management in the Home" [14]. As the book's title suggests, Frederick found her model in Taylorism, which had great success in rationalizing industrial enterprises. Frederick considered the kitchen as a company with only one employee $[12,14]$, and as a parallel to the rationalization experts of the factories, she identified the workflow in the kitchen in order to save time (see Fig. 2). She created an alternative kitchen: An efficient and time-saving kitchen meant only for cooking and with direct access to the dining area [5, 12]. However, Frederick's kitchen still consisted of separate elements that were not pieced together into an overall design. 


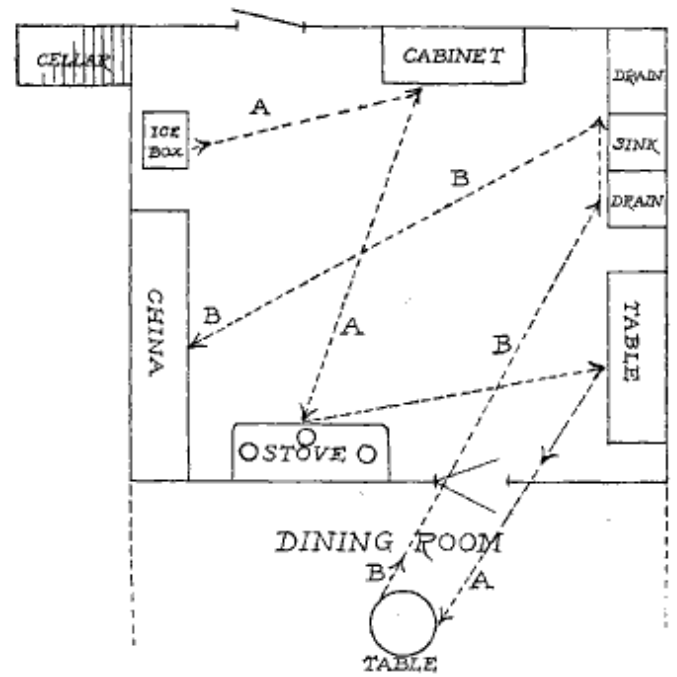

Diagram showing badly arranged equipment, which makes confused intersecting chains of steps, in either preparing or clearing away a meal.

(A-preparing; $\mathrm{B}$-clearing)

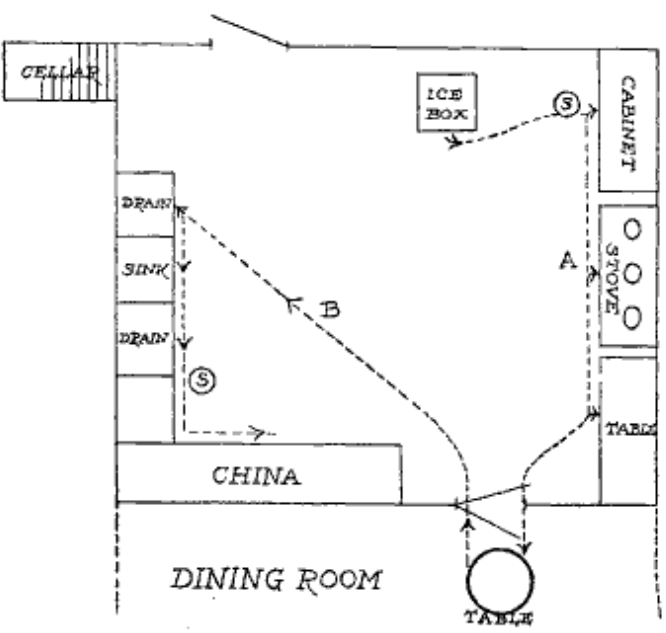

Diagram showing proper arrangement of equipment, which makes a simple chain of steps, in either preparing or clearing away a meal.

(A - preparing; B - clearing)

Fig. 2 On good and bad examples of floor plans, Christine Frederick [5] demonstrated how cooking could be implemented by time and step-saving devices.

The ambition to rationalize and streamline work in the kitchen had its base in a society where it was becoming ever more difficult for the middle class to hire servants [14]. Around the First World War, many women found work in factories where they earned more money and experienced independence. This left the middle-class kitchens without servants. Middle-class women had no experience of kitchen work, and therefore new tools and facilities were more than welcome.

Christine Frederick's book became almost a bible for architects at the Bauhaus working on developing a modern kitchen. At the first exhibition at Bauhaus in 1923, the German architect Adolf Meyer (1881-1929) presented a design of a modern kitchen. As Frederick had prescribed, the kitchen was rationally organized, and in line with Bauhaus' standardization efforts and vision of mass production, it was even conceived as units of elements with a continuous aesthetic expression.

Another important effort of modernism also became visible in Adolf Meyer's kitchen. The hygienic movement had enormous significance for the development of modernistic architecture [1, 10], and this topic was obvious in the field of kitchen design. Thus, Meyer's kitchen from 1923 had bright and shiny surfaces that could be kept clinically clean, and the traditional rows of plates were replaced by cupboard space where cooking utensils and tableware could be kept without gathering dust and without becoming greasy from gas and frying.

The hygienic movement in architecture is also evident in other kitchens, designed by contemporary modernists. Le Corbusier (1887-1965) pointed out the importance of using materials that are easy to clean, and he adhered to this religiously in his housing design. In the kitchen at Villa Savoye, not only the walls but also the kitchen tables are covered with white tiles (see Fig. 3). The kitchen, which previously had the character of a "workshop", transformed into a "laboratory" - clinically clean. In this context, electricity was considered a great revelation. It was for example reflected in the Weissenhof exhibition in 1927, where Josef Frank thematized "the electrical kitchen". Electricity was highlighted as a clean source of energy, without smoke and dirt like gas or charcoal. Furthermore, electricity made the position of appliances independent of chimneys etc. The electric 
kitchen could therefore be arranged optimally on the basis of the functional analyses.

The Frankfurt kitchen (Fig. 4) was the most famous example, where the modernistic ideals of kitchen design were realized and mass produced $[14,15]$. It was developed in 1926 by the Austrian architect Margarete Schütte-Lihotzky (1897-2000). She was part of a team around Ernst May, who in 1920 were tasked with building social housing in Frankfurt. Schütte-Lihotzky developed a number of standard kitchens, which were used in many houses [15]. The kitchens were simple and cheap, and they were constructed on the basis of an analysis of workflow and storage needs. Spatial dimensions were also determined in order to optimize workflow. In the Frankfurt kitchen the rooms were typically $1.90 \mathrm{~m} \mathrm{x}$ $3.44 \mathrm{~m}$ and similarly narrow and deep kitchens became common in contemporary housing — also in Denmark (see Fig. 5).

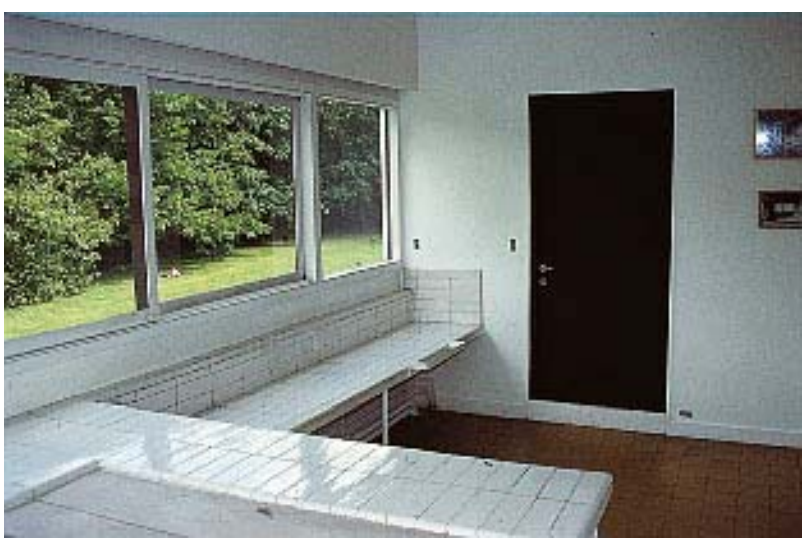

Fig. 3 In Villa Savoye of 1928, the kitchen is designed in line with the contemporary ideals of clinical hygiene. Everything is white and the tiles on the kitchen table are easy to clean.
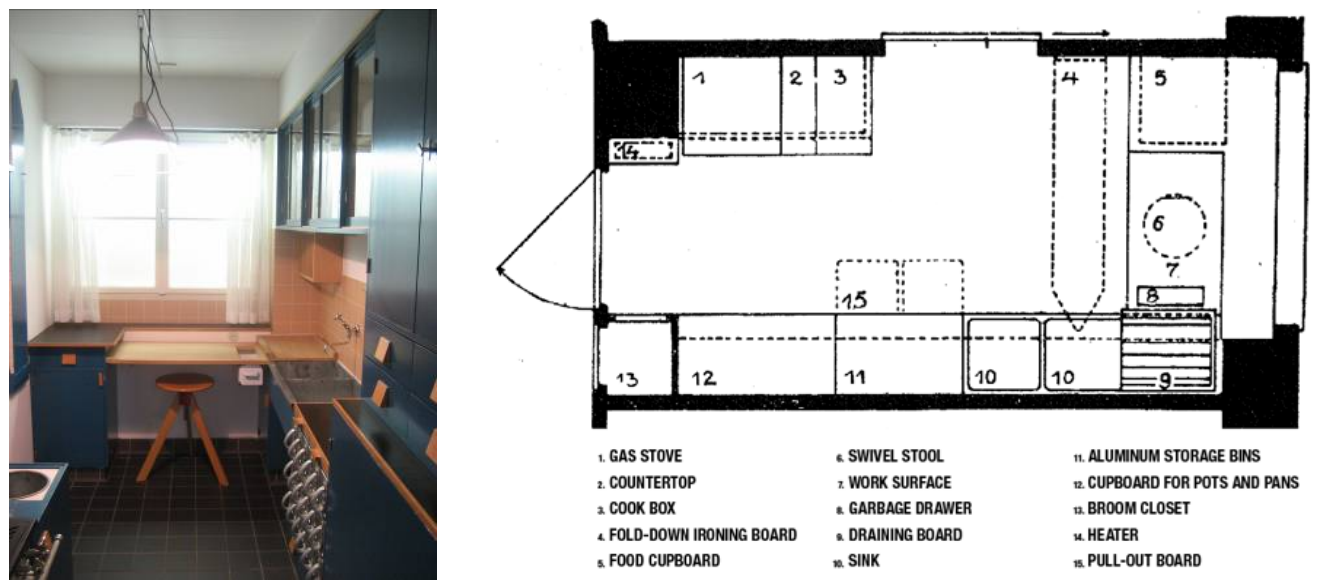

Fig. 4 The Frankfurt kitchen was designed for social housing in Frankfurt. It was the first mass-produced kitchen with a comprehensive design. Note the adjustable chair.
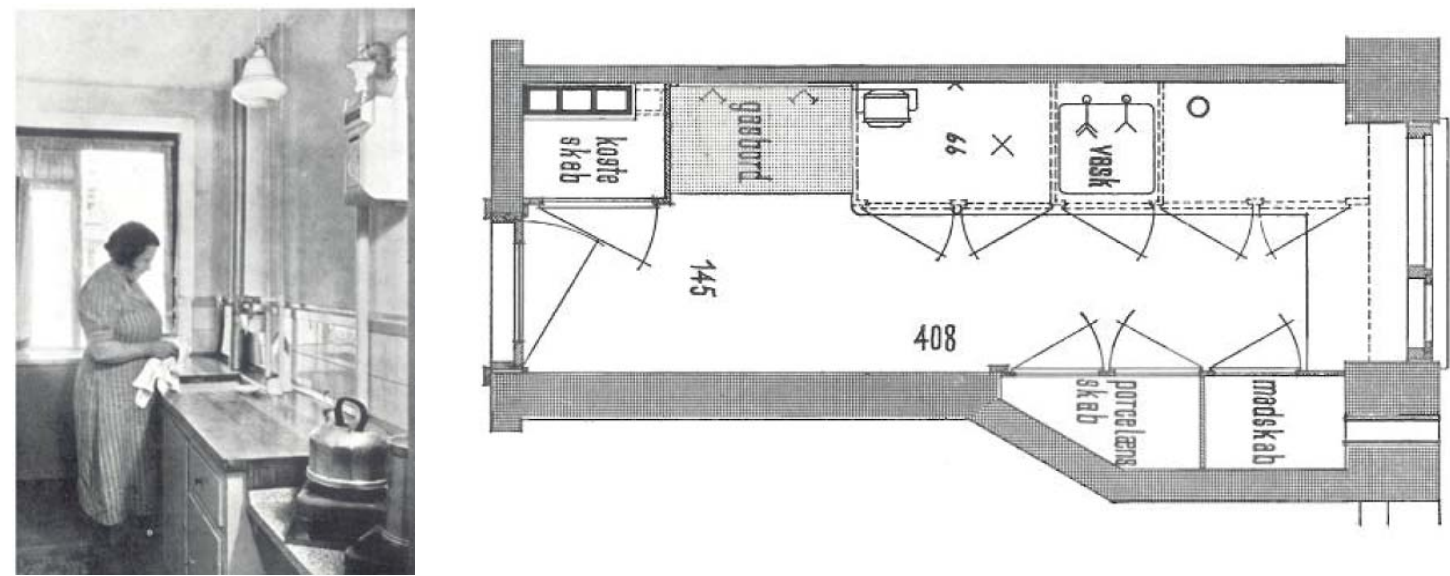

Fig. 5 A kitchen in the Danish social housing estate "Degnegaarden" from 1936. The deep and narrow space goes back to the Frankfurt kitchen. Degnegaarden was designed by Architects Cooperative - Alex Olsen, VagnKaastrup and Ole Buhl. 
In pure modernism the individual space in housing was optimized in relation to one specific function, and rationalization efforts were to dispel anything that was not related to traditional kitchen work, i.e., anything other than cooking and dishwashing. However, in smaller houses this requirement was often compromised. Schütte-Lihotzky developed a range of multifunctional solutions, such as a bathtub with a lid that could double as workstation when not in use [15]. On the one hand, inventive and innovative, on the other hand a sign that Schütte-Lihotzky still had roots in the traditional use of the kitchen for more than just cooking.

Modernist ideals of kitchens arrived rapidly in Denmark. It was for instance expressed by Edward Heiberg (1897-1958), one of the leading Danish functionalists. Kitchen work was in focus when Heiberg built a house for his wife and himself in 1925. They had no servants, and as stated by Heiberg, it was therefore important that it should be easy for his wife to cope with the household chores. Heiberg continued working with kitchens, as an architect, as well as a researcher. His motto for kitchen design was: "Not one unnecessary step” [17].

Despite being politically active and supporting equality between the sexes, Heiberg had no doubt about who was responsible for the household in his own home. Similarly the location of kitchens in modernistic white villas usually expresses a clear continuation of the division between masters and servants - despite the modernists' effort to break down the hierarchical social structure. The rooms for servants are located on the lower floor, together with other secondary rooms such as storage rooms, laundry room, etc.

Thus, wealthy families' kitchens were still a workplace for servants, but many middle-class families, who could no longer afford a staff, felt embarrassed about having to work in the kitchen themselves [3]. To those women who reluctantly worked in their own kitchen (as the servants disappeared), cooking was a chore [4]. In the general population, kitchen work was

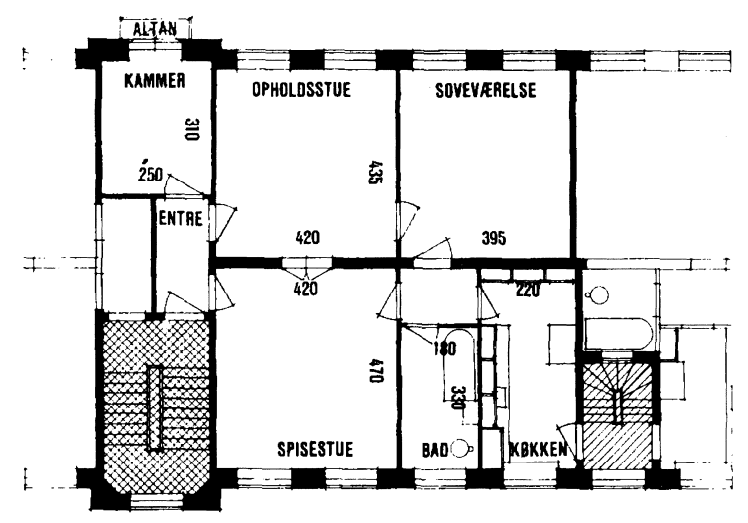

Fig. 6 The Danish housing estate, “Classens Garden” built in 1925. The apartment is very well equipped compared with other contemporary houses, for instance with a large bathroom with bath and a WC. The kitchen is located in the rear of all spaces with access from dining room through a corridor.

still associated with low status, and the kitchen continued to be regarded as a secondary space. It was hidden away in relation to the more presentable spaces of the dwelling, and there was often more than one door between the kitchen and dining room.

\section{Danish Kitchens - Functionalism in the 1950s}

After the Second World War, Europe had to be rebuilt and in Scandinavia the ideals of the welfare society were to be realized. In this context there was a socio-economic interest in getting more women into the labor market. By 1951 more than 20 percent of married women in Denmark worked outside the home. For comparison, this had only been the case for six percent in 1930 [18]. A study from 1954 showed that men's presence in the kitchen was still limited [14], and consequently there was a strong need to facilitate the housewife's domestic work.

However, only working class women had joined the labor market in earnest [18]. The middle-class families established themselves in the nuclear family with a housewife. The housewife was in charge of all domestic work, and as the families could no longer afford servants, she was alone in her kitchen. The kitchen, which had previously been the domain of the 
staff, was now the woman's room. This is reflected in the kitchen's location in the dwelling. In contrast to the pre-war kitchens, reserved for servants and hidden away, the kitchen now became a more integral part of the dwelling.

However, the kitchen was still not a part of the representative space. It was still a workplace for the housewife, and when guests came, she took off her apron, closed the door to the kitchen and welcomed the guests in the living rooms. There was still not much prestige in kitchen work and this was reflected in housing architecture. Kitchens were relatively small, they were designed for specific functions around cooking and washing - and you could close off the kitchen with a door.

In continuation of attempts in the 1920s and 1930s to develop functional and efficient kitchens, kitchens in the 1950s were also regarded as practical spaces [4]. Several measurements were made relating to space needs and room conditions in kitchens. This was partly as a continuation of the standardization processes, which enjoyed good conditions for growth in a post-war period with extensive housing shortages, and partly in an effort to facilitate domestic work and free female labor, so that women could participate in the labor market.

In Denmark Heiberg remained a leading figure in the debate on kitchen design and organization. In 1947 he developed a standardized kitchen for the Association of Social Housing and demonstrated that money could be saved by standardization: The kitchen was 20\% cheaper than similar kitchens erected on site [17]. At the Danish Building Research Institute, which was established in 1947, studies of conditions related to work in the kitchen were substantial research tasks. Kitchenwork was studied and divided into a number of sub-functions such as "washing”, "cooking”, "preparing food" etc, and the need for storage was identified. The clear division between the different functions had hygienic advantages and can be seen as a direct extension of the modernist hygienic ideals from the pre-war period, but more important was the time-saving potential. Time studies showed the amount of time that women spent in the kitchen, and that this time could be reduced through rational design.

The same functional perspective determined the location of the kitchen in the dwelling. In dwellings from the 1950s, the kitchen is no longer hidden away in a distant corner of the home. It is typically located next to the entrance hall (meaning that heavy shopping bags can quickly be put down on the kitchen table), and with direct access to the dining room (so that food and plates do not have to be carried too far).

Actually, reductions in time were not only achieved through the physical layout, but also the handling of shopping and cooking were rationalized and industrialized. Where government information on food and cooking today is typically about health, contemporary information focused on reductions in time and utilization of new technical aids. For instance, the Danish Households' Council [Statens Husholdningsråd] conducted studies on how much time a housewife could save by serving canned soup and machine-peeled potatoes [11].

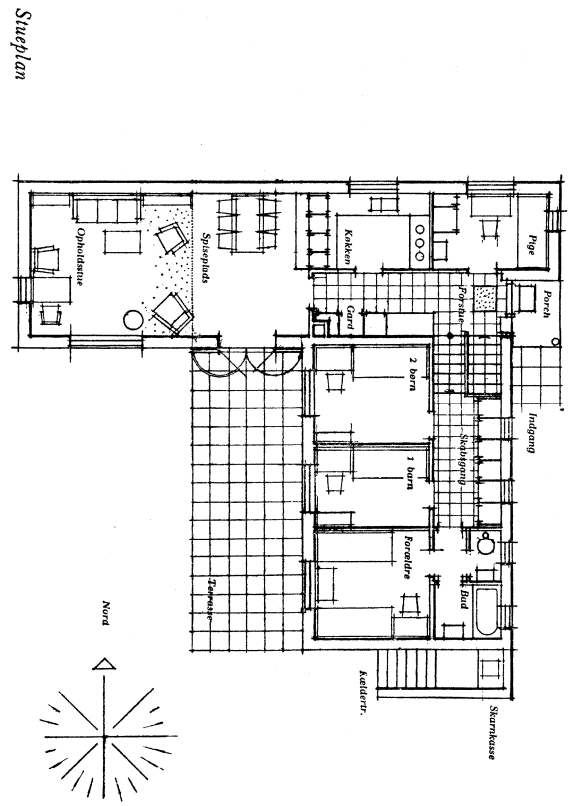

Fig. 7 Typical Danish detached housing from the 1950s. The dwelling is relatively small, as was dictated by governmental regulations, and the space in the kitchen is similarly small compared with today's standard. The kitchen is functionally placed in the house - near the entrance hall and close to the dining room. 
In the 1950s a softening took place regarding the modernists' concept of the mono-functional space designed solely for cooking and dishwashing. This was partly due to a series of studies conducted at the Danish Building Research Institute in the early 1950s. Research surveyed residents' use of their kitchens in contemporary housing, and the residents were asked whether there was anything they wanted to change. They replied that the kitchens were too small and that housewives wanted a small dining area in the kitchen.

The mono-functional space did not accommodate the life led by a modern nuclear family. The housewife served as the family hub, and it became clear that the concept of the mono-functional room was not so functional after all. The housewife had many functions besides cooking to take care of, for example helping the children with their homework, and the narrow spaces of the 1930s were criticized. On this background, Edvard Heiberg designed kitchens with small dining tables in the Copenhagen housing estate, "Bellahøj" (1950-1954). In the housing estate "Tingbjerg” (1955), another famous Danish architect, Steen Eiler Rasmussen, did likewise (see Fig. 8).

Thus, the dining kitchens of the 1950s were initially functionally justified. This is evident from a report published by The Danish Social Housing Association in 1949. The report states that a place for eating should be designed into the kitchen, but should not be so spacious as to detract from the functions of the living room [17]. The dining area in the kitchen was not meant to be a place for socializing, but as a practical set-up that made it easier for the housewife to watch the children and help them with their homework while cooking. Nevertheless, the kitchen dining area brought a lot of life into the kitchen and informal socializing developed. This was to have a great impact on the further development of the kitchen.

\section{Kitchen in the 1960s and 1970s}

In the early 1960s the nuclear family was still the societal ideal, and although women had increasingly entered the labor market, they still took care of the housekeeping at home. The kitchen remained the women's domain, but they were not alone in their kitchen anymore. A dining area as a part of the kitchen was becoming popular, and the dining table, which in the 1950s usually consisted of a small table in a cramped corner, had become larger.
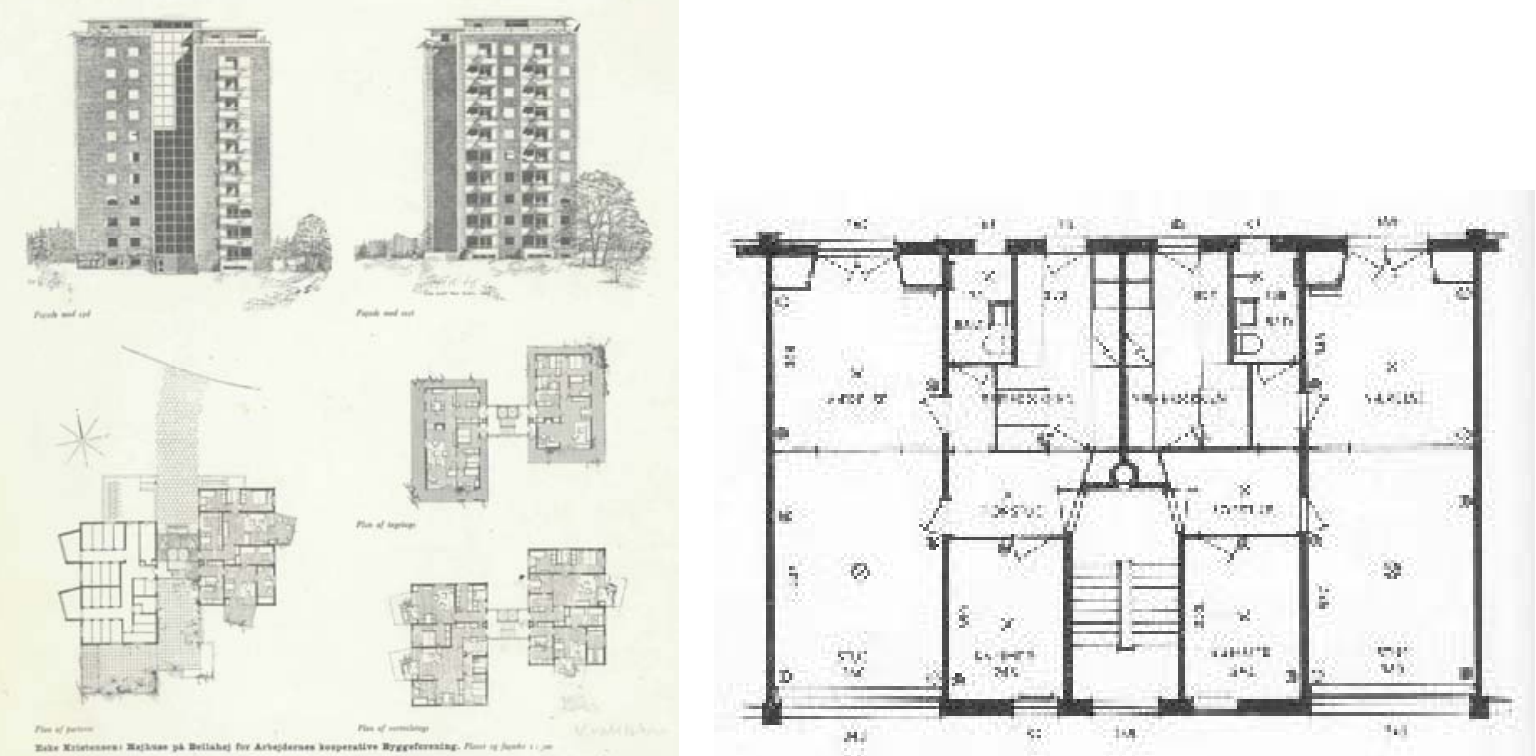

Fig. 8 Left: Bellahøj designed by Edward Heiberg et al. Right: Housing plan from Tingbjerg designed by Steen Eiler Rasmussen. 
Thus a new view on the kitchen developed. The kitchen was no longer a functional workspace, and the dining area in the kitchen was no longer seen only as a practical measure. In many homes the dining area in the kitchen developed into a cosy space for social activities. There was a special atmosphere in the kitchen, when the heat from hot plates and the smell from the oven filled the room. Eating and talking unfolded side by side with kitchen work, and an informal atmosphere developed in the kitchen. Initially, the kitchen retained its workspace atmosphere and was still not seen as a representative place. Danish kitchens of the 1960s were informal and practically furnished, and thus became a place where the family was together in a friendly and relaxed manner.

When guests were invited, they were still not invited into the kitchen, but during the week the dining room stood empty. The dining area in kitchens grew, and as it was now often located near the dining room, it felt strange to have two dining tables standing only a few meters apart. Obviously the next step was to break down the wall between the kitchen and the dining room [16]. The kitchen-dining area was born.

Thus, the kitchen and cooking came out of hiding. The kitchen became a central space in the house, and cooking became a visible part of everyday life. However, initially this did not lead to sophisticated kitchen design or the conversion of the kitchen into a new "best parlor". Quite the contrary, cooking was carried out with doughy hands and floury arms, and along with cooking utensils and kitchen appliances a relaxed atmosphere was created in the kitchen. This was perfectly inline with the rebellion against bourgeoisie correctness that took place in the 1970s.

Thus, the kitchen was still a practical workspace. However this should not lead to the misconception that kitchens had no representative value. This was very much the case, but it was not the aesthetics of the room that scored points. In contrast, the quality of the kitchen was in its informal character and the influence of this on the rest of the dwelling.
The youth rebellion took place in 1968, and many people felt that essential qualities were lost as a consequence of societal modernization. Economic status had become too dominant and in the search for values of more fundamental character, pre-modern society came into focus. Urban planners looked back, and in traditional rural settlements they found a social life that seemed to have been lost in the modern city. Also architects looked back and found inspiration in traditional housing: In a typical book from 1977 an American architect described, how the kitchen in Saxon dwellings from $900 \mathrm{BC}$ was a central space in the houses and served as the true "living room" [4]. Similar qualities were found by Danish architects in Nordic farm kitchens.

Looking back in time, the social significance of cooking and sharing a meal was rediscovered. A shared meal is one of the oldest exchange relationships between people, and many traditional rituals involve eating and drinking [13]. It was in this light that communal eating became important in the Danish community houses of the 1970s. They were set up in order to create social qualities and experiences between people. It was also time-saving when the residents in the communities took turns at cooking the meals, but the goal was not to increase societal production, but rather to allow time to be together.

All contemporary Danish low-density settlements had a common-house with a large kitchen. However, these kitchens were not installed at the expense of the kitchen in individual dwellings. The kitchen-dining area was an important space in the development of the family's sense of cohesion and it was a place to gather, where all family members could be heard.

Finally, the more central location of the kitchen within the dwellings of the 1970s is explained by changing gender roles. In many families the man increasingly began to take part in household work, and it is hardly a coincidence that at the same time kitchen work became visible in everyday life. The development of the exhaust hood that exhausts the smell of cooking 
and frying, facilitated this development. The delimiting walls could disappear, and the open kitchen-dining area was made possible.

This development of collective lifestyles, community houses and changing gender roles did not affect all families in the same way, but the ideals about kitchen design were nonetheless spread widely in Danish housing; in social housing as well as in detached houses. For instance in "Ishøj" — one of the largest contemporary social housing estates in Denmark — the individual dwellings were consistent with the ideals described. The open kitchens in Ishøj (see Fig. 9) are large and the dining table in the area between the kitchen and the sofa group is spacious, with room for at least six people.

\section{1980s until Today - Consumerism and Lifestyle Kitchens}

It is hard to point to one overarching trend in the architecture of this period. The architectural development took many directions, postmodernism made a break with modernism's functional analysis, and architecture was freed of its moral obligation. With the liberation of architectural design, it became obvious that personal taste was often crucial when consumers had to choose from a plethora of products, all covering the same functional needs [15]. Moreover it became increasingly clear that the design of products reflected values, and thus the products indirectly came to be

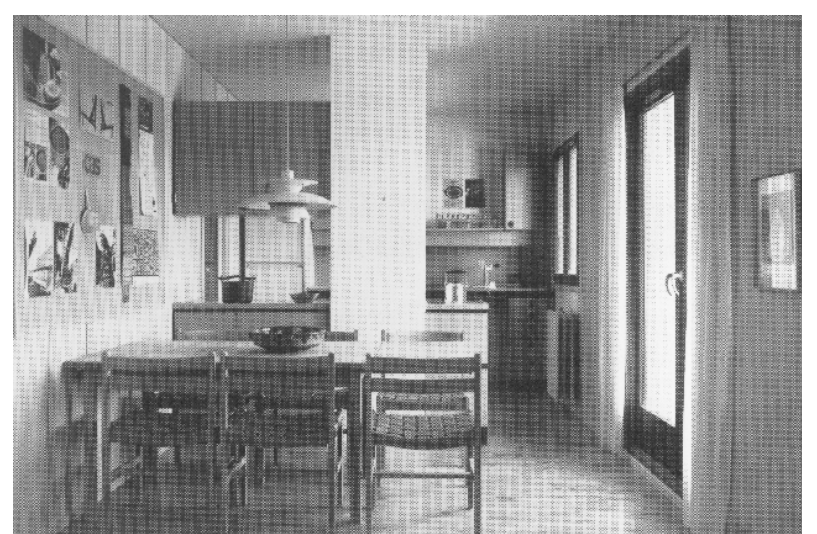

Fig. 9 Danish Social Housing in Ishøj from 1973. The spacious kitchen is part of the living area, and the dining table gives room for at least six people. expressive of those who bought the products. Choice of design became a matter of personality and identity [15].

A dwelling could therefore no longer be regarded as a "machine to live in" — and correspondingly a kitchen was not only a room for cooking. The kitchen was a designed product, reflecting opinions and personality, and not necessarily built to last as long as the dwelling itself. Since the functional properties no longer reigned supreme, a kitchen could be replaced - even though it still functioned well - if it was not in line with the residents' preference of taste. This kind of renewal and decoration in the dwelling may be called "lifestyle renovations" [2], and today's kitchens have been given a similar name: "lifestyle kitchens".

The dwelling has developed into an important place for residents' self-realization as well as a reflection of their personal identity, and kitchen design, details, materials and aesthetic take precedence over the functional [6]. The dwelling has turned into a mirror into which we look to find ourselves. Who are we, and what do we want to be like? That is what we seek when we decorate our dwelling and when we convert our kitchen. It is about finding your own style - about finding yourself [2].

Advertising agencies know this. An advertising campaign for a large Danish kitchen manufacturer (Invita) sells the idea of a kitchen as an individual and unique product. "It is not an 'Invita kitchen', it's a Mette and Lars kitchen," says the advertisement. Similarly, kitchen dealers say that they never supply two identical kitchens [6]. It is explained that the spaces to be furnished are different, the buyers have varying needs and financial situation, and that various materials, details, shapes and colors can be combined [6]. The question remains whether this differs from older kitchens? Modern kitchens are more standardized than ever before, and it can also be argued that older kitchens made specifically for a particular room were more individual than the new ones.

It is not the major technical innovations or architectural changes that characterize the kitchens of 
the two last decades. The kitchen-dining area is still the preferred type of kitchen, its location in the dwelling is equivalent to that which was developed in the 1970s, and the kitchen is still considered the central space in the house. Later literature on kitchen decor is not about new functional requirements and structural changes. Focus is rather on the kitchen "style". This is often apparent in categorized sections that present various styles: High-tech kitchen, the minimalist kitchen, the romantic country kitchen, etc. A consistent, general style of the period cannot be identified, but it can be pointed out that style is extremely important [7].

In general, the dwelling has rediscovered the representative character of the past, and this has become apparent in the design and shape of the kitchen. Where the kitchen of the 1970s was thought of as a workplace, able to tolerate the tough nature of kitchen work, kitchens in recent decades have seen an entirely different aesthetic approach. Where the informal nature of the kitchen was reflected in the adjoining rooms in the 1970s, today the representative qualities of the living rooms have influenced the kitchen. Light woods, brushed steel, and polished granite have become some of the preferred materials for exclusive kitchens (the use of the delicate materials was made possible because goods from the supermarket arrive in purified and processed form).

Today's lifestyle kitchens send out strong signals, and they work as a framework for self promotion. Like for instance, when guests are welcomed on a Friday night: a roast is in the oven, red wine has been poured, and a shiny kitchen bears witness that the host is in control of his life and apparently manages to cook in a trendy way. With the increased prosperity in society, focus is no longer on food as necessary for survival, and focus is less on the meal as a framework for social interaction. In today's lifestyle kitchen food expresses a family in control and with ability to appreciate and prepare fine cooking. Work in the kitchen is no longer hidden away behind closed doors.
However, repeatedly the question is being asked of whether today's large and prestigious kitchens actually form the setting for cooking. It has been argued, that our kitchens have become more and more spacious as we eat more and more fast food - and thus spend less and less time cooking. As early as the 1990s, the Italian scientist and designer Mondadori discussed this development and he pointed out that current kitchens reflect two concurrent trends. On the one hand he sees the emergence of "the fast-food home", where residents are increasingly buying ready-made meals, heating them in the microwave oven and eating them in front of the television. This can be seen as a further development of the trends of the 1950s, when the use of canned or other ready-made dishes was highlighted for the potential time savings.

On the other hand, Mondadori sees signs of the emergence of "the convent home", where cooking and meals are increasingly seen as a ritual part of a social community. Here, delicious recipes and culinary experiences are paramount, and "slow food" cooking is considered as part of a lifestyle rather than an abomination that should to be reduced and eliminated. The trend can be seen as a continuation of the 1970s organic movements and communities' rediscovery of cooking and meals as more than just putting food into your mouth. In this light, the kitchen becomes a space of the senses, where the experiences of exotic spices, colorful vegetables, the texture of materials and delicate tastes are some of the ingredients.

According to Mondadori, the two trends exist side by side - not only in the sense that different families choose to live in different ways and their neighbors do not necessarily share the same lifestyle, but also that trends can co-exist within one and the same family. The shift can happen between lunch and dinner, during the week, on weekends, etc. "With the same furniture and the same equipment, you can returnto medieval times, or you can move toward Star Wars”, writes Mondadori, seductively. The kitchen is open for dreams and these dreams will continue in the 21st century. 


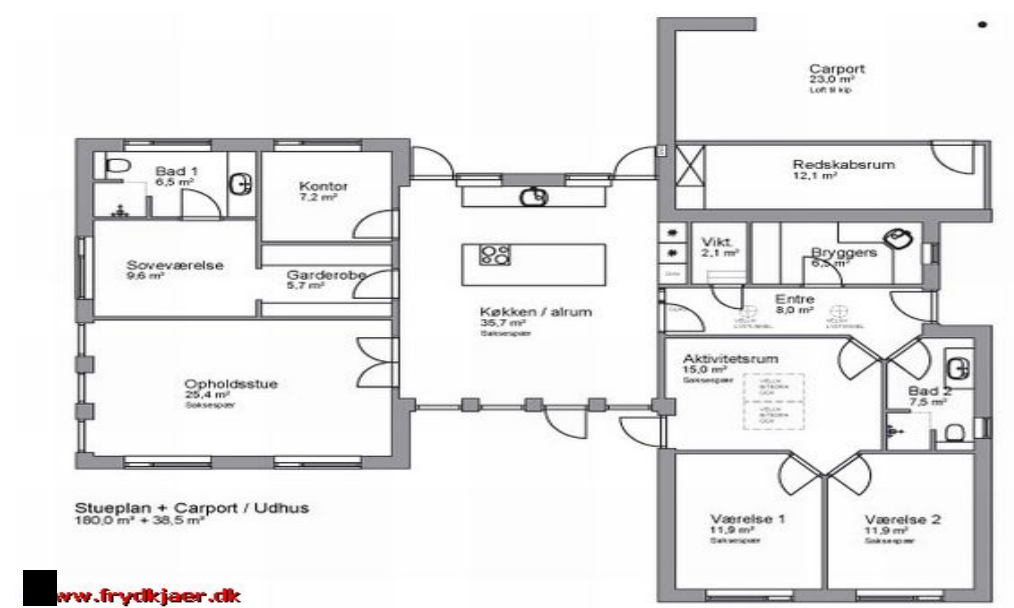

Fig. 10 Typical Danish detached housing from 2011. The kitchen is - as in the previous period - considered the central space in the house. However, today there is an increased emphasis on the kitchen "style".

\section{Conclusion}

This paper has shown how societal and cultural trends (for instance health, food culture, gender, sustainability, consumerism class, wealth, technology etc.) have influenced architectural design over the last 100 years. This has been done by focusing on the layout of the kitchen and kitchen design in European and Danish housing.

The following changes have been identified:

One hundred years ago, the kitchen of the bourgeoisie and the middle class was only used by servants and other employees - the kitchen was not designed for the residents. Therefore, the design of the kitchen and work in the kitchen were not associated with any prestige. Today we spend an enormous amount of money on decorating and designing our kitchens. One of the reasons for this is that the kitchen has become an important showcase for lifestyle and identity.

In the early 20th century, major efforts were made to streamline the workflow in the kitchen in order to save time. An important objective was to release the female workforce for the labor market. These trends are still detectable in today's kitchens - in the form of ready-made meals, microwaves and fast food. But at the same time "slow food" has become a trend. "Time" is a valuable asset today, and it is associated with high status to have the time, personal ability to cope and reserves of energy to prepare good food with the emphasis on quality.

At the beginning of the century, the kitchen was a secondary space. In villas the kitchen was situated side by side with the coalstore and servants' rooms in the basement, and in the large residential blocks in the city they were well hidden away in a far corner of the apartment. During the 20th century, the kitchen moved even further into the spotlight, and today it has developed into a central room of the home with great social qualities, and a lot of money is spent on the aesthetic appearance of the kitchen.

So fundamental changes have taken place in the kitchen over this relatively short period of time. Our view of the kitchen has undergone drastic changes and the physical location and layout of the kitchen have also developed dramatically. This can serve as a reminder that kitchens as well as housing will continue to change. Although many people have a firm concept of what a dwelling is, in fact the dwelling is changing constantly, both physically and mentally.

\section{References}

[1] Claus Bech-Danielsen, Moderne arkitektur — hva' er meningen? Copenhagen, Systime, 2004.

[2] Claus Bech-Danielsen and Kirsten Gram-Hanssen, Home-building and identity — The soul of a house and 
the personal touch, in: Urban lifescape: Anthology, Aalborg, Aalborg University Press, 2004.

[3] John Burnett, Social History of Housing: 1815-1970. Cambridge, The University Press, 1978.

[4] Terrence Conran, The Kitchen Book, New York: Crown Publishers Inc., 1977.

[5] Christine Frederick, The New Housekeeping: Efficiency Studies in Home Management, available online at: http://nationalhumanitiescenter.org/pds/gilded/progress/te xt4/frederick.pdf, Originally publ. in: Ladies. Home Journal, Sept.-Dec. 1912.

[6] Hans-Christian Jensen, Livsstilskøkkenet - "Alle har ret til et fedt køkken”, in: Dybdahl \& Engholm (ed.), Design: Køkkenet, København, Gyldendal, 2008.

[7] Gilly Love, Making the Most of Kitchens, London, Conran Octopus Ltd., 1997.

[8] Ellen Lupton and Abbott J. Miller, The Bathroom, The Kitchen, and the Aesthetics of Waste: A Process of Elimination, Cambridge, MIT List Visual Arts Center, 1992

[9] Arnoldo Mondadori (Ed.), Annual Cusina. Milano, September 1991.

[10] Paul Overy, Light, Air and Openness: Modern Architecture Between the Wars, London, Thames \& Hudson, 2008.
[11] Gerda Petri (Ed.), Kitchen.Denmark’s largest site, Ølgod: Ølgod Museum 1991.

[12] Janice Williams Rutherford, Selling Mrs. Consumer: Christine Frederick and the Rise of Household Efficiency, Athens, University of Georgia Press, 2003.

[13] Karen Lisa Salamon, Det universelle køkken fremtidens rum? in: Dybdahl \& Engholm (Ed.), Design: Køkkenet, København, Gyldendal, 2008.

[14] Anne-Louise Sommer, Fra ildstedskøkkenet til samtalekøkkenet, in: Dybdahl \& Engholm (Ed.), Design: Køkkenet, København, Gyldendal, 2008.

[15] Deyvan Sudjic, Home: The Twentieth-Century House, Glasgow, Festival Company Ltd, 1999.

[16] Sunset, The Magazine of Western Living, Western Kitchens, Menlo Park, Lane Publishing Co, 1955.

[17] Leif Leer Sørensen, Edvard Heiberg og dansk funktionalisme, En arkitektog hans samtid, København, Arkitektens Forlag, 2000.

[18] Birgitte Vorre, Boligen i det 20. århundrede. Indretning og brug, København, Nyt Nordisk Forlag Arnold Busk, 2008.

[19] Finn Werne, Arkitekturens ismer, Stockholm, Arkitektur Förlag AB, 1998. 